\title{
Slope Reinforcement Study Using Geotextile
}

\author{
Hairulla Hairulla*, Dina Limbong Pamuttu, Eko Budianto, Asep Sunandar, Daud Andang Passalli \\ Department Of Civil Engineering, Faculty of Engineering, Universitas Musamus, Merauke 99600, Indonesia
}

\begin{abstract}
The development of transportation in Indonesia causes the need for land for road use to increase. This encourages people to make the best use of every available land, one of which is in hilly and lowland areas and the topography tends to vary. The development of embankment slopes above the soil with less bearing capacity results in large subsidence and lateral movement. The purpose of this study was to determine the effect of using Geotextile type TS 600 as reinforcement in soils that have low bearing capacity. From the results of laboratory tests, it is known that Geotextile Type TS 600 can reduce deformation that occurs in soft soil. The deformation that occurs in unreinforced soil with a load of $4 \mathrm{kN}$ is $-45.5 \mathrm{~mm}$; while the deformation that occurs in the reinforced soil using geotextile type TS 600 layer 1 is $-40.31 \mathrm{~mm}$, layer 2 is $-35.15 \mathrm{~mm}$, and layer 3 is $-30.25 \mathrm{~mm}$. It is known that Geotextile Type TS 600 can reduce the deformation that occurs in soft soil.
\end{abstract}

Keywords: Geotextile, Slope, Reinforcement

\section{Introduction}

The increasing progress of transportation in Indonesia has resulted in an increase in the need for land for road use. This 'encourage humans to make the best use of every available land, one of which is in hilly areas and lowlands and the tofography tends to vary.

Merauke Regency is an area that has an area of $46,791.63 \mathrm{Km} 2$ or $14.67 \%$ of the total area of Papua Province and is the largest district in Papua Province. The condition of soil types that tend to have low soil bearing capacity, this is what causes practitioners to build a road with artificial slope reinforcement such as embankment slopes, road slopes, excavated slopes or dam slopes. In order to realize a construction that is comfortable, durable and of course safe, it is necessary to analyze the safety of artificial slopes in planning.

The level of safety of an artificial slope is influenced by several factors, including the slope factor and the load acting on it. Artificial slopes with large loads and steep slopes can cause landslides. This condition is of course very dangerous for the driver, so a slope reinforcement is needed. The use of geotextile and soil reinforcement is one of the technological innovations that has been widely used in recent years. The use of this geotextile can help in various planning, one of which is the reinforcement test of the slope using a non woven geotextile type TS 600 . With this problem, the author takes the title "Slope Reinforcement Modeling Study Using Geotextile".

\footnotetext{
* Corresponding author : hairulla@unmus.ac.id
}

\section{Materials and Methods}

\subsection{Types of research}

The design used in this study is an experimental study by carrying out a slope reinforcement test using the TS 600 type geotextile on a laboratory modeling scale.

\subsection{Location of Sampling}

The location of this research was conducted at the Civil Engineering Department Laboratory, Faculty of Engineering, Musamus University. The sample soil used came from the Wasur area, Merauke District, Merauke Regency.

\subsection{Method of Implementation}

\subsubsection{Sample Preparation}

The sample used consists of the original land obtained through the Wasur area, Merauke District, Merauke Regency. The geotextile material used in this implementation is the non woven Type TS600.

\subsubsection{Preparation of Equipment and Materials}

- Preparation of test equipment for physical and mechanical properties of the soil. 
- Soil reinforcement test inspection model using the geotextile Type TS600 material. Using a box made of $1.2 \mathrm{~cm}$ thick steel plate, which consists of steel which has dimensions $\mathrm{T}=50 \mathrm{~cm} \times \mathrm{W}=60 \mathrm{~cm} \times \mathrm{P}=$ $120 \mathrm{~cm}$.

- Hydraulic pump (Hydraulic Jack) : to put a load on the plate.

- Dial indicator (Dial Gauge) : to see the value of soil deformation in the test model.

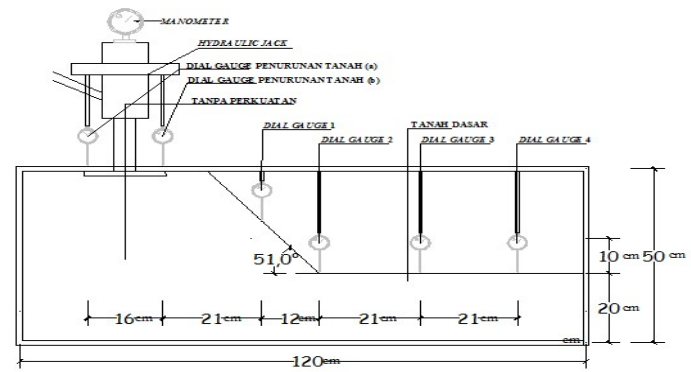

Fig. 1. Laboratory modeling schematic

\subsubsection{Research Implementation}

- Testing of water content is adjusted to SNI. [1] The tools used are ovens, cups, electric scales.

- Testing of soil density is adjusted to SNI. [2] The tools used are hot plates, picnometers, ovens, electric scales, spatulas.

- Testing of grain analysis is adjusted to SNI. [3] The tools used are sieve filters, brushes, electric scales, water hoses, cups.

- Atterberg boundary testing devices are adjusted to SNI. [3], [4] Test equipment used is casagrande, cup, glass with dimensions of $0.9 \mathrm{~cm} \times 45 \mathrm{~cm} \times 45 \mathrm{~cm}$, spatula, oven.

- Compaction test equipment adjusted to SNI. [5] The tools used are ovens, standard hammer proctors, standard proctors, electric scales, jacks.

\section{Materials and Methods}

\subsection{Soil Classification}

In this study, the results of laboratory tests for grain size that passed filter no. 200 is $88.38 \%$ because greater than $35 \%$ is classified as clay soil and in the AASHTO classification system it belongs to groups A-4 to A-7.

\subsection{Soil Properties}

The table belowis a recapitulation of the results of the physical and mechanical properties of the soil in the laboratory with soil materials from the wasur area :
Table 1. Recapitulation of the physical and mechanical properties of the soil

\begin{tabular}{|c|c|c|c|}
\hline No. & Checking type & Symbol & $\begin{array}{l}\text { Test } \\
\text { result }\end{array}$ \\
\hline \multicolumn{4}{|c|}{ Sample specific examination } \\
\hline 1 & Water content in the field & $\mathrm{wc}$ & $14.74 \%$ \\
\hline 2 & Specific Gravity & GS & $2.60 \%$ \\
\hline \multicolumn{4}{|c|}{ Sieve Analysis Examination } \\
\hline 3 & Pass cumulative no. 200 & - & $88.38 \%$ \\
\hline \multicolumn{4}{|c|}{ Atterberg test } \\
\hline 4 & Liquid Limit & LL & $38.41 \%$ \\
\hline 5 & Plasticity Limit & PL & $10.74 \%$ \\
\hline 6 & Plasticity Index & PI & $27.67 \%$ \\
\hline \multicolumn{4}{|c|}{ Content weight test } \\
\hline 7 & Fill Weight & $\gamma$ & $\begin{array}{c}1.83 \mathrm{~g} / \\
\mathrm{cm}^{3}\end{array}$ \\
\hline \multicolumn{4}{|c|}{ Compaction test } \\
\hline 8 & $\begin{array}{l}\text { Maximum Dry Volume } \\
\text { Weight }\end{array}$ & $\gamma \mathrm{d}$ & $\begin{array}{c}1,975 \mathrm{~g} / \\
\mathrm{cm}^{3}\end{array}$ \\
\hline 9 & Optimum Water Content & & $11.25 \%$ \\
\hline
\end{tabular}

\subsection{Laboratory Testing Results}

In slope strengthening studies using geotextile loading on laboratory scale testing using load sizes with values ranging from $0.5 \mathrm{KN}, 1 \mathrm{KN}, 1.5 \mathrm{KN}, 2 \mathrm{KN}, 2.5 \mathrm{KN}, 3$ $\mathrm{KN}, 3.5 \mathrm{KN}, 4 \mathrm{KN}$ by using a hydraulic jack press. The deformation of the inspection results without the reinforcement of the TS 600 geotextile type based on the analysis of the results of laboratory investigations can be seen in table 2. Below.

Table 2. Settlement without reinforcement geotextile

\begin{tabular}{|c|c|c|c|c|c|c|}
\hline \multirow[b]{2}{*}{$\begin{array}{l}\text { Load } \\
(\mathrm{KN})\end{array}$} & \multirow{2}{*}{$\begin{array}{c}\text { Settlem } \\
\text { ent } \\
\text { Dial A } \\
(\mathrm{mm})\end{array}$} & \multirow{2}{*}{$\begin{array}{l}\text { Settlem } \\
\text { ent Dial } \\
\text { B }(\mathbf{m m})\end{array}$} & \multicolumn{4}{|c|}{ Deformation Reading } \\
\hline & & & $\begin{array}{c}\text { Dial } \\
1\end{array}$ & $\begin{array}{c}\text { Dial } \\
2\end{array}$ & $\begin{array}{c}\text { Dial } \\
\mathbf{3}\end{array}$ & $\begin{array}{c}\text { Dia } \\
14\end{array}$ \\
\hline 0 & 0 & 0 & 0 & 0 & 0 & 0 \\
\hline 0.5 & -25.16 & -25.16 & 10,12 & 9.5 & 6.19 & $\begin{array}{l}6.1 \\
5\end{array}$ \\
\hline 1 & -25.57 & -25.57 & 11.15 & 10,12 & 7.25 & $\begin{array}{l}6.3 \\
5\end{array}$ \\
\hline 1.5 & -28.34 & -28.34 & 12.54 & 11.25 & 8.58 & $\begin{array}{l}6.4 \\
8\end{array}$ \\
\hline 2 & -32.79 & -32.79 & 13.73 & 12.32 & 9.37 & $\begin{array}{l}6.7 \\
3\end{array}$ \\
\hline 2.5 & -37.32 & -37.32 & 14.64 & 13.45 & 10.46 & $\begin{array}{l}7.0 \\
8\end{array}$ \\
\hline 3 & -40.2 & -40.2 & 15.82 & 14.91 & 11.33 & $\begin{array}{l}7.1 \\
5\end{array}$ \\
\hline 3.5 & -42.65 & -42.65 & 16.58 & 15.76 & 12.21 & $\begin{array}{l}7.5 \\
6\end{array}$ \\
\hline 4 & -45.5 & -45.5 & 17.26 & 16.18 & 13.85 & $\begin{array}{l}8.2 \\
8\end{array}$ \\
\hline $\begin{array}{c}\text { Dista } \\
\text { nce } \\
(\mathrm{cm}) \\
\end{array}$ & 0 & 16 & 37 & 49 & 70 & 91 \\
\hline
\end{tabular}

In table 2 above, it can be seen that the deformation that occurs with a $4 \mathrm{kN}$ load on the unweighted soil is -45.5 $\mathrm{mm}$. Deformation that occurs can be seen in Figure 2. 


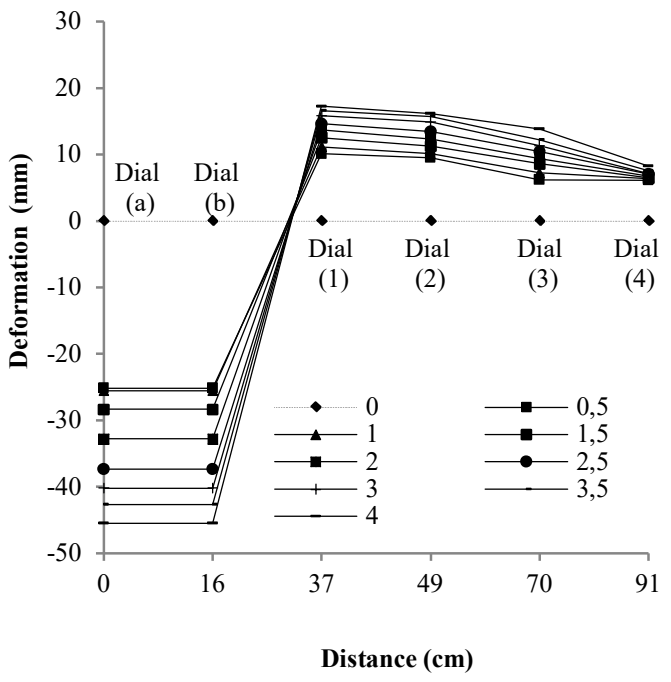

Fig. 2. Graph of soil without reinforcement

Deformation that occurs in dial $1=17.26 \mathrm{~mm}$, deformation of dial $2=16.18 \mathrm{~mm}$, deformation of dial 3 $=13.85 \mathrm{~mm}$ and deformation of dial $4=8.28 \mathrm{~mm}$. Dial drop (a) and dial drop (b) $=-45.5 \mathrm{~mm}$.

Table 3. Settlement with 1 layer geotextile reinforcement

\begin{tabular}{|c|c|c|c|c|c|c|}
\hline \multirow{2}{*}{$\begin{array}{c}\text { Load } \\
(\mathbf{K N})\end{array}$} & \multirow{2}{*}{$\begin{array}{c}\text { Sett. Dial } \\
\mathbf{A}(\mathbf{m m})\end{array}$} & \multirow{2}{*}{$\begin{array}{c}\text { Sett. Dial } \\
\mathbf{B}(\mathbf{m m})\end{array}$} & \multicolumn{4}{|c|}{ Deformation Readings } \\
\cline { 4 - 7 } & $\mathbf{D i a l} 2$ & Dial 3 & $\begin{array}{c}\text { Dial } \\
\mathbf{4}\end{array}$ \\
\hline 0 & 0 & 0 & 0 & 0 & 0 & 0 \\
\hline 0.5 & -20.12 & -20.12 & 8,12 & 7.23 & 5.15 & 5.05 \\
\hline 1 & -21.23 & -21.23 & 9.46 & 8.54 & 6.75 & 5,22 \\
\hline 1.5 & -25.08 & -25.08 & 10.75 & 9.65 & 7.61 & 5.48 \\
\hline 2 & -28.25 & -28.25 & 11.21 & 10.85 & 8.23 & 5.75 \\
\hline 2.5 & -30.09 & -30.09 & 12.19 & 11.52 & 9,16 & 6.13 \\
\hline 3 & -33.17 & -33.17 & 13.23 & 12.42 & 10,17 & 6.35 \\
\hline 3.5 & -37.12 & -37.12 & 14.37 & 13.55 & 11.54 & 6.47 \\
\hline 4 & -40.31 & -40.31 & 15.71 & 14.28 & 12.77 & 7.25 \\
\hline $\begin{array}{c}\text { Dist. } \\
(\mathrm{mm})\end{array}$ & 0 & 16 & 37 & 49 & 70 & 91 \\
\hline
\end{tabular}

In Table 3 above, it is known that the deformation that occurs with a load of $4 \mathrm{kN}$ on the soil reinforced with the Type TS 600 geotextile is $-40.31 \mathrm{~mm}$. The deformation that occurs can be seen in Figure 3.

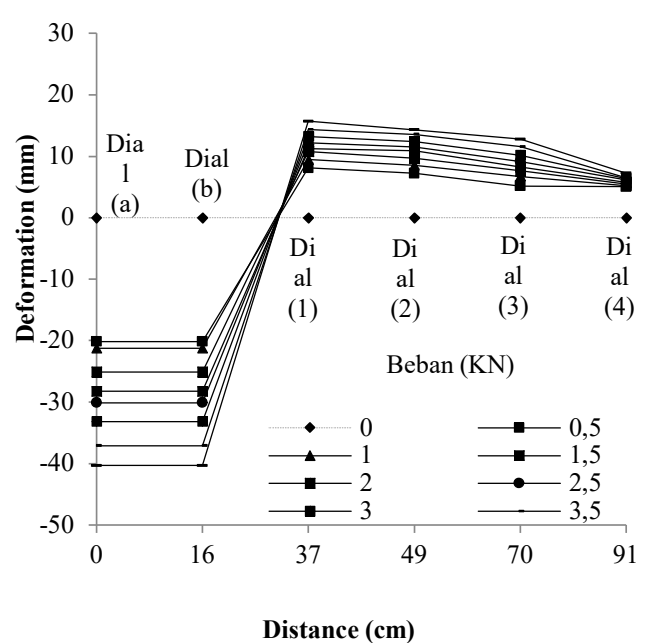

Fig. 3. Soil graph with 1 layer geotextile type TS 600 reinforcement

In the graph 3 above, it has changed from before. The increase in deformation in 1 layer geotextile reinforcement, namely dial 1 deformation $=15.71 \mathrm{~mm}$ dial 2 deformation $=14.28 \mathrm{~mm}$ dial deformation $3=$ $12.77 \mathrm{~mm}$ and dial-deformation $4=7.25 \mathrm{~mm}$. Drop of dial (a) and dial (b) $=-40.31 \mathrm{~mm}$.

Table 4. 2-layer geotextile reinforcement

\begin{tabular}{|c|c|c|c|c|c|c|}
\hline \multirow[b]{2}{*}{$\begin{array}{l}\text { Load } \\
(\mathrm{KN})\end{array}$} & \multirow{2}{*}{$\begin{array}{c}\begin{array}{c}\text { Settle } \\
\text { ment } \\
\text { Dial A } \\
(\mathbf{m m})\end{array} \\
\end{array}$} & \multirow{2}{*}{$\begin{array}{c}\text { Settleme } \\
\text { nt Dial B } \\
\text { (mm) }\end{array}$} & \multicolumn{4}{|c|}{ Deformation Readings } \\
\hline & & & $\begin{array}{c}\text { Dial } \\
1\end{array}$ & $\begin{array}{c}\text { Dial } \\
\mathbf{2}\end{array}$ & $\begin{array}{c}\text { Dial } \\
\mathbf{3}\end{array}$ & $\begin{array}{c}\text { Dial } \\
4\end{array}$ \\
\hline 0 & 0 & 0 & 0 & 0 & 0 & 0 \\
\hline 0.5 & -19.04 & -19.04 & 7.35 & 6.52 & 4.15 & 4.13 \\
\hline 1 & -20.1 & -20.1 & 8.57 & 7.46 & 5.25 & 4.25 \\
\hline 1.5 & -23.12 & -23.12 & 9,13 & 8.53 & 6.46 & 4.57 \\
\hline 2 & -25.21 & -25.21 & $\begin{array}{l}10.3 \\
7\end{array}$ & 9.25 & 7.35 & 4.75 \\
\hline 2.5 & -28.11 & -28.11 & $\begin{array}{l}11.3 \\
9\end{array}$ & 10.2 & 8.24 & 5.24 \\
\hline 3 & -30.51 & -30.51 & $\begin{array}{l}12.4 \\
2\end{array}$ & $\begin{array}{l}11.1 \\
5\end{array}$ & 9.43 & 5.35 \\
\hline 3.5 & -33.07 & -33.07 & $\begin{array}{l}13.1 \\
5\end{array}$ & $\begin{array}{l}12.5 \\
5\end{array}$ & $\begin{array}{l}10,1 \\
7\end{array}$ & 5.45 \\
\hline 4 & -35.15 & -35.15 & $\begin{array}{l}14.2 \\
6 \\
\end{array}$ & $\begin{array}{l}13.9 \\
2\end{array}$ & $\begin{array}{l}11.6 \\
3 \\
\end{array}$ & 6.73 \\
\hline $\begin{array}{l}\text { Distan } \\
\text { ce } \\
(\mathrm{mm})\end{array}$ & 0 & 16 & 37 & 49 & 70 & 91 \\
\hline
\end{tabular}

The deformation movement shown in table 4 at $4 \mathrm{KN}$ load has increased the strengthening, that is, the deformation on dial 1 is $14.26 \mathrm{~mm}$, dial 2 deformation = $13.92 \mathrm{~mm}$, dial 3 deformation $=11.63$ and dial 4 deformation $=6.73 \mathrm{~mm}$. Dial decrease (a) and dial decrease (b) $=35.15 \mathrm{~mm}$. 


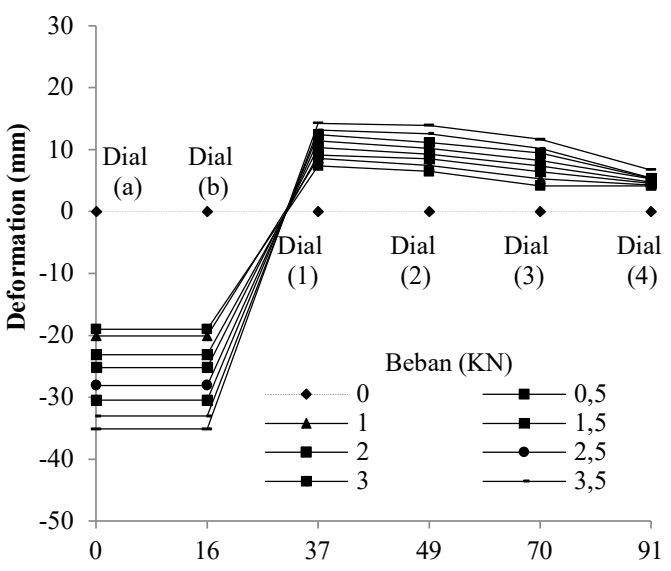

Distance (cm)

Fig. 4. Soil graph with 2 layers of geotextile type TS 600 reinforcement

Based on the analysis of the 3-layer geotextile reinforcement at $4 \mathrm{KN}$ loading, the reinforcement has increased with a result of $-30.25 \mathrm{~mm}$. The overall results from $0.5 \mathrm{KN}$ to $4 \mathrm{KN}$ loading can be seen in table 5 below.

Table 5. Reduction with 3 layers of geotextile reinforcement

\begin{tabular}{|c|c|c|c|c|c|c|}
\hline \multirow{2}{*}{$\begin{array}{l}\text { Load } \\
(\mathrm{KN})\end{array}$} & \multirow{2}{*}{$\begin{array}{c}\text { Settlemen } \\
\text { t Dial A } \\
(\mathbf{m m})\end{array}$} & \multirow{2}{*}{$\begin{array}{l}\text { Settlem } \\
\text { ent Dial } \\
\text { B }(\mathbf{m m})\end{array}$} & \multicolumn{4}{|c|}{ Deformation Readings } \\
\hline & & & Dial 1 & $\begin{array}{c}\text { Dial } \\
2\end{array}$ & $\begin{array}{c}\text { Dial } \\
\mathbf{3}\end{array}$ & $\begin{array}{l}\text { Dia } \\
14\end{array}$ \\
\hline 0 & 0 & 0 & 0 & 0 & 0 & 0 \\
\hline 0.5 & -16.01 & -16.01 & 5.21 & 4.03 & 3.5 & $\begin{array}{c}3.0 \\
5\end{array}$ \\
\hline 1 & -16.4 & -16.4 & 6.11 & 6.21 & 4,3 & $\begin{array}{c}3.2 \\
5\end{array}$ \\
\hline 1.5 & -17.2 & -17.2 & 7,13 & 7,12 & 5.18 & $\begin{array}{c}3.5 \\
2\end{array}$ \\
\hline 2 & -18.3 & -18.3 & 8.15 & 8.22 & 6.05 & $\begin{array}{c}3.7 \\
5\end{array}$ \\
\hline 2.5 & -20.5 & -20.5 & 9.23 & 9.42 & 7.66 & $\begin{array}{c}4.0 \\
2\end{array}$ \\
\hline 3 & -23.75 & -23.75 & 10.35 & $\begin{array}{c}10.1 \\
1 \\
\end{array}$ & 8.43 & $\begin{array}{c}4.0 \\
5 \\
\end{array}$ \\
\hline 3.5 & -25.45 & -25.45 & 11.57 & $\begin{array}{c}11.1 \\
6\end{array}$ & 9,13 & $\begin{array}{c}4.6 \\
7\end{array}$ \\
\hline 4 & -30.25 & -30.25 & 12.17 & $\begin{array}{c}12.3 \\
2\end{array}$ & $\begin{array}{c}10.5 \\
5\end{array}$ & 5.5 \\
\hline $\begin{array}{l}\text { Dista } \\
\text { nce } \\
(\mathrm{mm})\end{array}$ & 0 & 16 & 37 & 49 & 70 & 91 \\
\hline
\end{tabular}

The deformation movement shown in table 4 at $4 \mathrm{KN}$ load has increased the strengthening, that is, the deformation on dial 1 is $12.17 \mathrm{~mm}$, dial 2 deformation = $12.32 \mathrm{~mm}$, dial 3 deformation $=10.55$ and dial 4 deformation $=5.5 \mathrm{~mm}$. Dial drop (a) and dial drop $(\mathrm{b})=$ $-30.25 \mathrm{~mm}$.

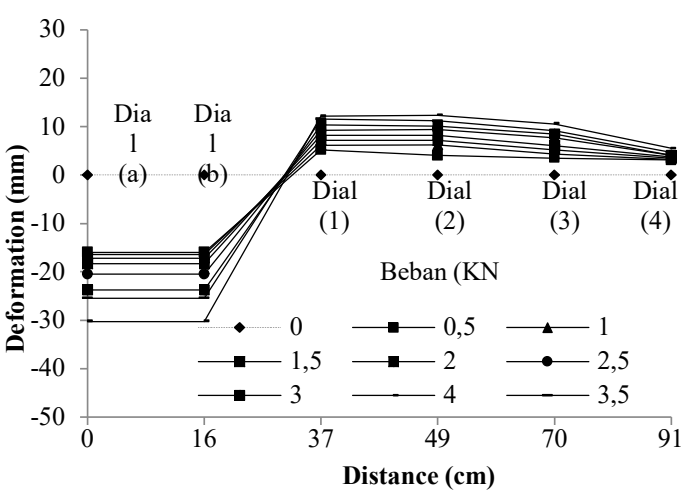

Fig. 5. Soil graph with 2 layers of geotextile type TS 600 reinforcement

Based on the analysis of laboratory test results, data-ton the subsidence that occurs in the soil is obtained, it is known that the subsidence that occurs in unreinforced soil at a load of $4 \mathrm{kN}$ is $-45.5 \mathrm{~mm}$, while the settlement that occurs on reinforced soil using geotextile type TS 600 with a 1 layer model the $4 \mathrm{KN}$ load is -40.31 , while the 2-layer and 3-layer models are -35.15 and -30.25 , respectively. The results of all loading are shown in Figure 4 below.

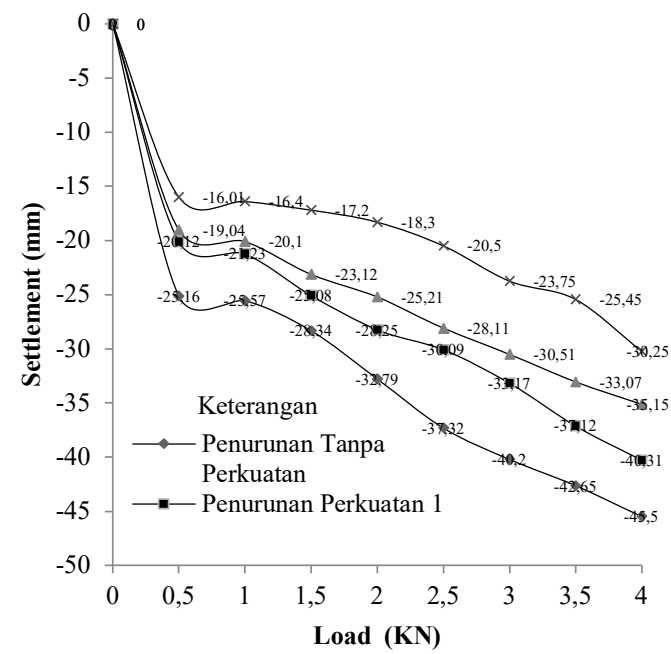

Fig. 6. Graph of the increase in the reinforcement of the TS 600 geotextile type

\section{Conclusion}

Based on the results of tests in the laboratory, Geotextile non woven type TS 600 as reinforcement material can increase bearing capacity and decrease in soft soil on physical modeling of embankment slopes. The percentage of soft soil reinforcement using geotextile type TS 600 on the 1-layer model increased by $11.40 \%$ 
and the 2-layer and 3-layer models increased by $22.74 \%$ and $33.51 \%$, respectively.

\section{References}

1. Anonymous. Testing Methods for Aggregate Moisture Content, (SNI 03 - 1971 - 1990). National Standard Agency, Jakarta. (1990)

2. Anonymous. Soil Plastic Boundary Testing Methods, (SNI 03-1966-1990). National Standard Agency, Jakarta. (1998)

3. Anonymous. How to Test Analysis of Soil Grain Size. (SNI 3423 : 2008). National Standard Agency, Jakarta. (2008)

4. Sazuatmo. The Effect of Plastic Materials on Shear Strength in Clay Soil. UBI Civil Engineering Journal, Vol. 2 No. 1 : 110 \& 115. 2011

5. Anonymous. How to Test Heavy Density For Soil. (SNI 1743 : 2008). National Standard Agency, Jakarta. ( 2008) 